\title{
Örgütsel Adalet ile Örgütsel Bağlılık Arasındaki Illişkide Örgütsel Güvenin Aracılık Etkisi
}

\author{
The Effect of Organizational Trust as a Mediator Role on the Relationship between \\ Organizational Justice with Organizational Commitment
}

\author{
Yrd. Doç. Dr. Yılmaz Akgündüz - Yrd. Doç. Dr. Tülay Güzel
}

\begin{abstract}
Öz
Örgütsel adaletin ve örgütsel güvenin çalı̧̧anların işletmeye karşı olan tutumlarını etkilediği bilint mektedir. Bu çalışmanın amacı, örgütsel adaletin çalışanların örgütsel bağllikklarına etkisini ve bu etkide örgütsel güvenin aracllk rolünü belirlemektir. Bu amaçla, Örgütsel Güven Ölçeği, Örgütsel Adalet Ölçeği ve Örgütsel Bağlllık Ölçeğinden yararlanarak bir anket oluşturulmuştur. Anket kolayda örnekleme yöntemi ile Istanbul'daki 5 yıldızlı otel çalışanlarına 1 Temmuz-15 Aralık 2013 döneminde uygulanmiştır. Araştırmaya 276 otel çalışanı katılmıştır. Yapısal eşitlik modellemesi ile yapılan analiz sonucunda; dağıtımsal adaletin ve işlemsel adaletin örgütsel bağlllı̆̆ pozitif olarak etkilediği belirlenmiştir. Ancak örgütsel güven aracı değişken olarak modele dahil edildiğinde sadece işlemsel adalet ile örgütsel bağhllı arasinda örgütsel güvenin aracilı rolüne sahip olduğu belirlenmiştir. Bu sonuçlara bağIt olarak yöneticilerin işlemsel adalet uygulamalar gerçekleştirerek, çalı̧̧anların hem örgütsel güvenlerini hem de örgütsel bağlilıklarını artırmalarının mümkün olabileceği söylenebilir.
\end{abstract}

Anahtar Kelimeler: Örgütsel Adalet, Örgütsel Güven, Örgütsel Bağlllık, Otel İşletmeleri

\footnotetext{
Abstract

It is known that the organizational justice and organizational trust have effect on employees' attitudes towards business. This study mainly has two aims, first of which is to investigate the effect of organizational justice on organizational commitment, and the second
}

one is to investigate the mediator role of organizational trust in this effect. To achieve this goal, a questionnaire has been formed via the scales of organizational justice, organizational trust, and organizational commitment. Questionnaire has been applied with the convenience sampling method to five star hotel employees in Istanbul between 1 July and 15 December in 2013. 276 hotel employees have participated in the research, totally. Structural equation modeling has been applied in statistical analysis. As a result; it distributive justice and procedural justice have a positive effect on organizational commitment. When organizational trust has been added into model as a mediator, significant relation has been observed only between procedural justice and organizational commitment. Hence, it could be said that employees' organizational trust and organizational commitment could be increased by the help of implication of procedural justice by the managers.

Keywords: Organizational Justice, Organizational Trust, Organizational Commitment, Hotel Businesses

\section{Giriş}

Otel işletmelerinde çalışanların örgüt amaçları doğrultusunda motive olmalarında, örgüte karşı duydukları güven önemlidir (DeConick, 2010, s.1350). Çalışanların örgüte güven duymalarında ise örgüt içerisindeki ilişkiler, alınan kararlardaki ve uygulamalardaki hakkaniyet önemli bir belirleyicidir. Çalışanların işletmedeki kararların hakkaniyetli olarak

Yrd. Doç. Dr. Yllmaz Akgündüz, Mersin Üniversitesi Turizm Fakültesi, yilmazakgunduz@hotmail.com Yrd. Doç. Dr. Tülay Güzel, Çanakkale Onsekiz Mart Üniversitesi Turizm Fakültesi, tuguzel@yahoo.com 
alındığına inanmaları ve örgüte güven duymaları, iş tatminlerini artırarak çalışanları örgüte bağlı hale getirecektir (Hon ve Lu, 2010, s.674).

Örgütsel bağlılık çalışanları örgüte bağlayan dengeleyici bir güçtür (Bentein vd., 2005, s.470). Örgüte bağlı işgörenler örgütün amaçlarını ve değerlerini kabul ettikleri ve örgütte kalmak istedikleri (Mowday vd., 1979, s.230) için her örgüt çalışanların örgütsel bağlılığını artırmak istemektedir (Bayrak Kök, 2006, s.299). Örgütsel bağlllığ $\operatorname{artan}$ çalışanlar daha fazla sorumluluk almak istemekte ve performansını yükselterek örgütsel amaçlara daha fazla katkıda bulunmaktadırlar (Chow, 1994, s.5).

$\mathrm{Bu}$ çalışmanın amacı, örgütsel adaletin çalışanların örgütsel bağlllıklarına etkisini ve bu etkide örgütsel güvenin aracılık rolünü belirlemektir. Bu kapsamda öncelikli ilk bölümde örgütsel adalet, örgütsel güven ve örgütsel bağlılık kavramları ele alındıktan sonra araştırma modeline bağlı olarak geliştirilen hipotezler sunulmuştur. Araştırmanın yöntemi bölümünde ise araştırma ile ilgili yöntem, verilerin analizi ve bulgulara yer verilmiştir. Son bölümde araştırmaya ilişkin sonuçlara ve önerilere değinilmiştir.

Araştırma kapsamında önerilen hipotezleri test etmek için yapılan yapısal eşitlik modellemesi sonucunda otel işletmelerinde dağıtımsal adaletin, işlemsel adaletin ve örgütsel güvenin çalışanların örgütsel bağlılığını pozitif olarak etkilediği; işlemsel adaletin örgütsel güveni pozitif olarak etkilemesine rağmen dağıtımsal adaletin örgütsel güven üzerinde anlamlı bir etkisinin olmadığı belirlenmiştir. Ayrıca araştırmada otel işletmelerinde örgütsel güvenin işlemsel adalet ve örgütsel bağlılık arasındaki ilişkide aracılık rolüne sahip olmasına rağmen; dağıtımsal adalet ile örgütsel bağlılık arasındaki ilişkide aracılık rolüne sahip olmadığ 1 belirlenmiştir.

\section{Kuramsal Çerçeve}

\section{Örgütsel Adalet}

Örgütsel adalet ile ilgili çalışmalar Adams’ın Eşitlik Teorisi ile başlamaktadır. Bu teoriye göre çalışanlar elde ettikleri kazanımları hem çalışma arkadaşlarının kazanımları hem de başka örgütlerde benzer durumlarda olan çalışanların kazanımları ile karşılaştırırlar (Robbins ve Judge, 2011, s.255). Kazanımlar arasında bir benzerlik olduğuna inanırlarsa, çalıştığı örgütün hakkaniyetli bir örgüt olduğu sonucuna varırlar. Örgütsel adaleti, değişim teorisine ile de açıklamak mümkündür. Bu teoriye göre çalışanlar eğitim düzeylerini, becerilerini, tecrübelerini ve örgüttteki çabalarını kazanımları ile karşılaştırırlar. Karşılaştırma sonunda çalışanların adalet algısının düşük olması durumunda devamsızlık artışı, işe geç gelme ve istifa gibi davranışsal tepkilerinin dışında, performanslarında da azalma görülmektedir (Mullins, 2007, s.126-135).

Örgütsel adalet işyerindeki adalete-hakkaniyete- ilişkin çalışanların algılarını kapsamaktadır (Johnson vd. 2006, s.178). Adaletli bir örgütte yöneticilerin davranışları çalışanlar tarafından adil, ahlaki ve rasyonel olarak değerlendirilir (İşçan ve Sayın, 2010, s.196). Böyle örgütlerde, örgüt içi uygulamalar keyfiliğe göre değil, eşitlik temeline göre yürütülür (Koys ve DeCotiis, 1991, s.267).

Çalışanlar bir örgütün adaletli olup-olmadığını işletme yönetimin uygulamalarına göre değerlendirirler. Yönetimin uygulamaları hakkında genel bir kanıya vardıktan sonra çalışanların adalet algısı oluşur (Şahin ve Taşkaya, 2010, s.101). Çalışanların örgüte yönelik güçlü bir adalet algısı oluşması durumunda, çalışanlar kendilerini örgütün değerli bir parçası olarak hissettikleri için yöneticileriyle daha fazla uyum içinde çalışırlar. Ancak çalışanların yönetim uygulamalarında, özellikle ödüllerin dağılımında adaletsizlik olduğuna inanmaları durumunda örgütsel bağlılık ve örgütsel vatanaşlık başta olmak üzere örgütsel değerlendirmelerinde olumsuzluklar olmaktadır (Skarlicki ve Folger, 1997, s.435).

Örgütsel adalet; dağıtımsal adalet, işlemsel adalet ve etkileşimsel adalet olarak üç boyutta ifade edilmektedir (Greenberg, 1993, s.85; Colquitt, 2001, s.388-389). Dağıtımsal adalet görevler, mallar, hizmetler, firsatlar, cezalar/ödüller, roller, statüler, terfiler, ücretler vb. karşılaşılan sonuçların ya da ödüllerin hakkaniyeti ile (İşcan ve Naktiyok, 2004, s.187); işlemsel adalet kazanımlara yol açan süreçlerin hakkaniyeti ile ilgilidir. Etkileşimsel adalet ise örgütsel uygulamaların kişilerarası yönüne odaklı, iletişim sürecinde nezaket ve dürüstlük gibi yönleri esas alan adalet türüdür (Bies ve Moag, 1986, s.48). Etkileşimsel adalet çoğunlukla işlemsel adaletin bir alt boyutu olarak kabul edildiği için (Tyler ve Bies, 1990, s.78; Mcfarlin ve Sweeney, 1992, s.626) bu çalışma kapsamında örgütsel adalet; dağıtımsal adalet ve işlemsel adalet olmak üzere iki boyutta incelenmiştir. 


\section{Örgütsel Güven}

Örgütlerde işbirliğine odaklı kültürün gelişmesinde güven işlemsel bir role sahiptir. Farklı yaşam tecrübesine sahip örgüt çalışanlarını bir arada tutabilmek için güven esastır (Mayer vd. 1995, s.709). Ayrıca güvenin örgütlerde tutum, algı, davranış ve performans çıtıları üzerinde belirleyici bir etkisi vardır (Dirks ve Ferrin, 2001:450). Örgütsel güven; Mishra ve Morrisey (2000, s.14-15) tarafından işgörenlerin örgütün kendilerine sağladığı desteğe ilişkin algıları, yöneticinin doğru sözlü olacağına ve sözünün ardında duracağına ilişkin inancı olarak; Memduhoğlu ve Zengin (2011, s.213) tarafından ise çalışanların birbirlerinin ve yöneticilerinin yeterliklerine, adil, hoşgörülü ve etik ilkelere bağl1 kararlar alma ve uygulama sürecine olan inancı olarak ifade edilmiştir.

İşgörenler için örgütsel güven hem yöneticileriyle hem de birlikte çalıştığı iş arkadaşları ile olan ilişkilerinde belirleyicidir (Mishra ve Morrissey, 2000, s.14). Örgütlerde işbirliğini desteklemek ve daha yüksek performans çıtılarına ulaşmak için örgütsel güven bir zorunluluk olarak görülmektedir (Dirks ve Ferrin, 2001, s.450). Örgütsel güvenin yüksek olması verimliliğin, iş tatmininin ve örgütsel bağlılığın artması; devamsızlık ve işten ayrılmanın azalması gibi istenen örgütsel çıktılarla ilgilidir (Gregory vd. 2007, s.119; Kath vd., 2010, s.1492-1493).

$\mathrm{Bu}$ çalışma kapsamında örgütsel güven; işletmeye güven, yöneticiye güven ve çalışma arkadaşlarına güven olmak üzere üç boyutta ele alınmıştır. İşletmeye güven, işgörenlerin riskli durumlarla karşılaştıklarında örgütün davranışlarının tutarlı olduğuna dair inançları (Demircan ve Ceylan, 2003, s.142); yöneticiye güven işgörenlerin yöneticinin yapmış olduğu açıklama ve vermiş olduğu sözlere dayanan inançları (Deluga, 1994, s.315); çalışma arkadaşlarına güven ise işgörenlerin çalışma arkadaşlarının hareketlerine, dürüstlüklerine ve iyi niyetlerine yükledikleri inançları olarak ifade edilmektedir (Tokgöz ve Aytemiz Seymen, 2003, s.63). İşletmeye, yöneticisine ve çalışma arkadaşlarına güven duyması işgörenin örgütün amacı için çaba harcamasını, işine bağlı olmasını ve motivasyonunun yüksek olmasını sağlayacaktır (İşçan ve Sayın, 2010, s.203).

\section{Örgütsel Bağlılık}

Örgütsel bağlılık; bir çalışanın örgütün amaçlarını kabul etmesi, örgütte kalma ve örgütün lehine çaba gösterme istekliliği (Angle ve Perry, 1986, s.31); çal1- şanların çıkarlarından çok örgütün çıkarlarına önem verme ve örgütün çıkarlarını koruyacak şekilde davranma eğilimi (Kundi ve Saleh, 1993, s.154) olarak tanımlanmıştır. Örgütsel bağllı̆ı̆ı anlayabilmek için hem çalışanları hem de örgütsel uygulamaları incelemek gerekir (Mowday vd. 1979, s.224). Örgütsel bağlilık uyum, özdeşleşme ve içselleştirmeden oluşan bir süreç olarak kabul edilmiştir (Aronson, 1999, s.179). Uyum süreci çalışanların ödül elde etmek veya cezadan kaçmak için sergilediği tutum ve davranışları; özdeşleşme süreci çalışanların diğer çalışma arkadaşlarıyla ilişkilerini korumak amacıyla onların etkisini kabul etmesi ve onlara benzeme isteği; içselleştirme ise çalışanların örgütün değerleri ile kişisel değerleri arasinda uyum hissetmesidir (O'Reilly, 1989, s.17). Çalışanlar süreci tamamladıklarında örgütsel bağl1lıkları oldukça yükselmektedir.

Meyer ve Allen (1991, s.61-89) örgütsel bağlılı̆̆ı; devam bağllılığı (maliyete dayalı), duygusal bağlılık (isteğe dayalı) ve normatif bağlılık (zorunluluğa dayalı) olmak üzere üç boyutta açıklamıştır. Duygusal bağlılığ güçlü olan çalışanlar örgütte istedikleri için, devam bağl1lı̆̆ı güçlü çalışanlar ihtiyaç duydukları için, normatif bağlllığı güçlü çalışanlar ise zorunlu oldukları için örgütte kalırlar. Başka bir anlatımla devam bağlılığ çalışanların örgütten ayrılması durumda ortaya çıkacak maliyetleri göze alamaması ile ilgili; normatif bağlılık çalışanların örgütte kalmayı kendileri için bir görev olarak görmeleri ve örgütte kalmanın ahlaki bir davranış olması ile ilgili; duygusal bağl1lık ise çalışanların örgütün amaçlarını ve değerlerini benimsemesi, örgütün amaçlarına ulaşabilmesi için örgütün bir parçası olarak çaba göstermesi ile ilgilidir (Uyguç ve Çımrın, 2004, s.92-93). Çalıştığı örgüte karşı olumlu tutum ve davranışa neden olan duygusal bağll1ık, örgütsel bağlılığının en ideal şekli olarak kabul edilmektedir (Brown, 2003, s.41).

\section{Araştırma Modeli ve Hipotezleri}

Turizm işletmelerinde sunulan hizmetin müşteriyi tatmin edebilmesi için çalışanlar arasında yakın işbirliği gerekir. $\mathrm{Bu}$ işletmeler için çalışanların örgütsel güven duygularının ve örgütsel bağlllıklarının yüksek olması, örgütsel amaçların başarılmasında oldukça önemlidir. Ayrıca çalıştığı bir işletmeye güvenmeyen çalışanların iş tatmin düzeyinin düşük olduğu göz önünde bulundurulduğunda, kendisi tatmin olmamış bir çalışanın müşteri tatminini sağlayabilmesi oldukça zordur. 


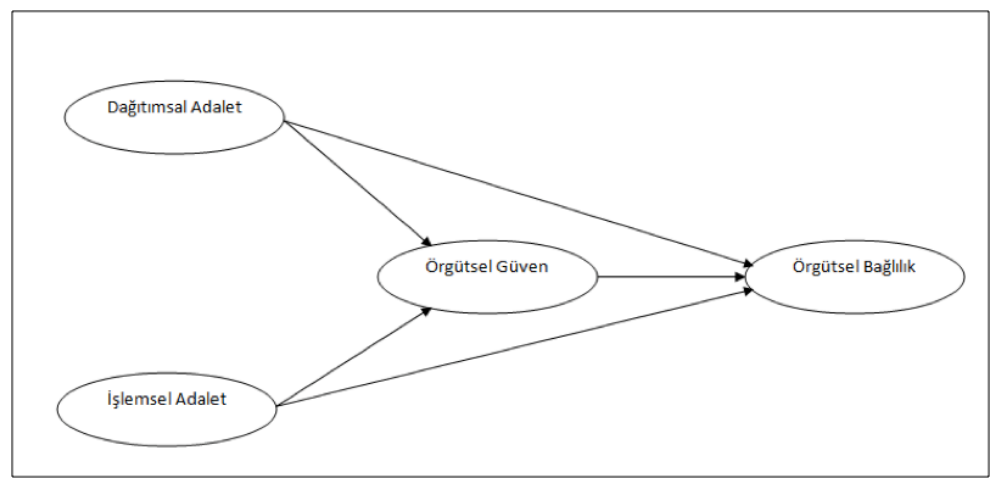

Şekil 1. Araştırma Modeli

Örgütsel adalet algısı olumlu olan çalışanların, örgütsel bağlılıkları diğer çalışanlara göre daha yüksek olmaktadır. Yapılan çalışmalarda (İşçan ve Naktiyok, 2004, s.181; Aslantürk ve Şahan, 2012, s.135) örgütsel adalet algısının örgütsel bağlıllğ pozitif etkilediği belirlenmiştir. Otel işletmeleri örnekleminde yapılan bu çalışmada, örgütsel adaletin çalışanların örgütsel bağlılığını pozitif etkilemesi beklenmektedir. Bu nedenle örgütsel adaletin örgütsel bağlllık üzerindeki etkisini belirlemek amaciyla $\mathrm{H}_{1 \mathrm{a}}$ ve $\mathrm{H}_{1 \mathrm{~b}}$ hipotezleri geliştirilmiştir.

$\mathrm{H}_{1 \mathrm{a}}$ : Dağıtımsal adaletin çalışanların örgütsel bağlılığı üzerinde olumlu bir etkisi vardır.

$\mathrm{H}_{1 b}$ : İşlemsel adaletin çalışanların örgütsel bağlılığ 1 üzerinde olumlu bir etkisi vardır.

Örgüt içerisinde çalışanların yöneticilerine ve çalışma arkadaşlarına güven duymaları, işletmeye yönelik tutumlarını olumlu olarak etkilemektedir. Yapılan araştırmalarda (DeConnick, 2010, s.1349; İşçan ve Sayın, 2010, s.211) örgütsel adalet uygulamalarının çalışanların örgütsel güvenlerini etkilediği belirlenmiştir. Otel işletmelerinde yapılan bu çalışmada, örgütsel adalet uygulamalarının çalışanların örgütsel güvenlerini pozitif olarak etkilemesi beklenmektedir. Bu etkiyi belirlemek amaciyla $\mathrm{H}_{2 \mathrm{a}}$ ve $\mathrm{H}_{2 \mathrm{~b}}$ hipotezleri geliştirilmiştir.

$\mathrm{H}_{2 \mathrm{a}}$ : Dağıtımsal adaletin çalışanların örgütsel güveni üzerinde olumlu bir etkisi vardır.

$\mathrm{H}_{2 \mathrm{~b}}$ : İşlemsel adaletin çalışanların örgütsel güveni üzerinde olumlu bir etkisi vardır.
Yapılan çalışmalarda örgütsel güvenin örgütsel bağl1lı̆̆ını artırdığı (Taşkın ve Dilek, 2010, s.43-44; Çakınberk ve Demirel, 2010, s.103) belirlenmiştir. Bu çalışmada farklı alanlarda ortaya konulmuş olan örgütsel güven ve örgütsel bağllık ilişkisini otel çalışanları örnekleminde belirlemek amacıyla $\mathrm{H}_{3}$ hipotezi geliştirilmiştir.

$\mathrm{H}_{3}$ : Örgütsel güvenin çalışanların örgütsel bağlılı$\breve{g} 1$ üzerinde olumlu bir etkisi vardır.

Yukarıdaki çalışmalarda belirtildiği ve Şekill'de gösterildiği gibi hem örgütsel adalet hem de örgütsel bağlılık, örgütsel güven ile ilişki içerisindedir. Bu nedenle işletme içerisinde örgütsel adaletin desteklemesi, çalışanların örgütsel güvenlerini artıracaktır. Böylelikle çalışanların örgütsel bağlılığı olumlu yönde etkilenebilecektir. Ancak bu ilişkide örgütsel güvenin hem örgütsel adalet ile hem de örgütsel bağlllık ile ilişki içinde olmasi; örgütsel güvenin örgütsel adaletin bir fonksiyonu olarak ortaya çıkması; örgütsel adaletin, çalışanların örgütsel bağlılı̆ğ üzerindeki etkisinde örgütsel güvenin aracıllk rolünün olabileceğini akla getirmektedir. Bu aracilık etkisini test etmek amaciyla $\mathrm{H}_{4 \mathrm{a}}$ ve $\mathrm{H}_{4 \mathrm{~b}}$ hipotezleri geliştirilmiştir.

$\mathrm{H}_{4 \mathrm{a}}$ : Örgütsel güven, işlemsel adalet ile örgütsel bağlılık arasındaki ilişskide aracılık etkisine sahiptir.

$\mathrm{H}_{4 \mathrm{~b}}$ : Örgütsel güven, dağıtımsal adalet ile örgütsel bağlılık arasındaki ilişkide aracılık etkisine sahiptir. 


\section{Araştırma Yöntemi}

\section{Araştırmanın Evren ve Örneklemi}

Araştırmanın evrenini, İstanbul'da faaliyet gösteren 5 yıldızlı otel işletmeleri oluşturmaktadır. Başbakanlık Bilgi Edinme Biriminden alınan bilgiye göre İstanbul'daki 58 adet 5 yıldızlı otel işletmesinde toplam 15185 oda bulunmaktadır. Günümüz Türkiye koşullarında odabaşına 0,80 personel istihdam edildiğinden (Çakıcı ve Yılmaz, 2012, s.9) hareketle evren büyüklüğü 12148 kişi olarak tahmin edilmiștir. Örneklem büyüklügü $\% 95$ güven düzeyinde ve $\% 5$ örneklem hatası ile 373 kişi olarak hesaplanmıştır (Sekaran, 1992, s.253).

Araştırmada veriler 1 Temmuz- 15 Aralık 2013 döneminde toplanmıştır. Ankete cevap veren tüm çalışanlar örnekleme dahil edilmek istendiği için olasılığa dayalı olmayan örnekleme yöntemlerinden kolayda örnekleme yöntemi tercih edilmiştir. Ancak izin sorunları nedeniyle belirlenen örneklem büyüklüğüne ulaşılamamıştır. Anket uygulama dönemi sonunda geçerli 276 anket toplanabilmiştir. Veriler bilgisayar ortamına aktarıldıktan sonra tanımlayıcı istatistiklerin dışında güvenilirlik ve geçerlilik analizlerine bağlı olarak çalışmanın hipotezlerini test etmek için yapısal eşitlik modelinden yararlanılmıştır.

\section{Veri Toplama Aracı}

Araştırmada veriler, alan yazına dayalı olarak geliştirilen bir anket ile toplanmıştır. Ankette katılımcıların demografik özelliklerini belirlemeye yönelik 6 adet kapalı uçlu sorunun dışında üç ölçek yer almaktadır.

Araştırmanın ilk ölçeği, dağıtımsal adaleti (4 madde) ve işlemsel adaleti (7 madde) belirlemek amaciyla Colquitt (2001, s.389) tarafından geliştirilen Örgütsel Adalet Ölçeğiidir (Organizational Justice Scale). Araştırmanın ikinci ölçeği, Tokgöz ve Aytemiz Seymen'in (2013, s.67) Whitener vd. (1998, s.513-530), Mayer vd. (2005, s.874-888) ve McAllister'in (1995, s.24-59) ölçeklerinden yararlanılarak geliştirdikleri Örgütsel Güven Ölçeğidir. Bu ölçek; işletmeye güven (8 madde), yöneticiye güven (10 madde) ve çalışma arkadaşlarına güven (9 madde) olmak üzere üç boyuttan oluşmaktadır.

Araştırmada yararlanılan son ölçek, Meyer ve Allen (1991, s.61-89) tarafından geliştirilen 17 maddelik Örgütsel Bağl1lık Ölçeği'dir. Bu ölçek; duygusal bağl1lık (6 madde), devam bağlllı̆̆ (6 madde) ve normatif bağlılık (5 madde) boyutlarından oluşmaktadır. Örgütsel güven ve örgütsel bağlllık ölçeklerinin yanıt kategorileri Kesinlikle Katılmiyorum (1), Kesinlikle Katılıyorum (5) olacak şekilde; örgütsel adalet ölçeğinin yanıt kategorileri ise Hiçbir Zaman (1) ve Her Zaman (5) olacak şekilde beşli likert derecelemesinde ifade edilmiştir.

\section{Bulgular}

Araştırmaya, İstanbulda faaliyet gösteren otel işletmelerinde çalışan 276 kişi katılmıştır. Araştırmaya katılanların \%39’u (107 kişi) kadın, \%61’i (164 kişi) erkektir. \%67'si (183 kişi) bekar, \%33'ü (91 kişi) evlidir. \%20'si (53 kişi) ilköğretim, \%48’i (126 kişi) lise ve \%32'si (84 kişi) üniversite mezunudur. \%23'ü (62 kişi) 25 yaş ve altında, \%58’i (155 kişi) 26 ile 35 yaş arasında, \%19'u ise 36 yaş ve üstündedir. Araştırmaya katılanların \%32'si (88 kişi) 5 yıl ve daha az iş tecrübesine, $\% 68$ 'i ise (185 kişi) 6 yll ve daha fazla iş tecrübesine sahiptir. \%52'si (138 kişi) “1500 ve daha az gelir elde ederken, \%48’i (127 kişi) "1501 ve daha fazla gelir elde etmektedir.

Örgütsel güven, örgütsel adalet ve örgütsel bağlllık ölçeklerinin geçerliliğini test etmek için doğrulayıcı faktör analizi yapılmıştır. Örgütsel adalet ölçeğinin iki faktörlü yapısı, örgütsel güven ölçeğinin ve örgütsel bağlılık ölçeğinin üç faktörlü yapısı ölçme modeli ile test edilmiştir.

Örgütsel Adalet Ölçeğinin geçerliliğini belirlemek için yapılan doğrulayıcı faktör analizi sonuçları Tablo 1.de yer almaktadır. Ölçeğin faktör analizi sonucu elde edilen standardize değerlerin l'in altında ve $\mathrm{t}$ değerlerinin 1,96'ın üzerinde olduğu görülmektedir. Örgütsel Bağlılık değişkenine ilişkin doğrulayıcı faktör analizi sonuçları Tablo 2'de yer almaktadır.

Tablo 2.de yer alan örgütsel bağlllık ölçeğine ilişkin standardize değerlerin l'in altında, $t$ değerlerinin 1,96'ı üzerinde olduğu görülmektedir. Tablo 3'de örgütsel güven ölçeğine ilişkin doğrulayıcı faktör analizi sonuçları yer almaktadır.

Örgütsel güven ölçeğine yönelik yapılan doğrulayıcı faktör analizi sonucunda yöneticiye güven boyutundaki 1 madde ve çalışma arkadaşlarına güven boyutundaki 1 maddenin $t$ değeri 1,96'in altında olduğu için analizden çıkartılarak, doğrulayacı faktör analizi tekrarlanmıştır. Tablo 3.de yer alan 25 maddeli ör- 
Tablo 1. Örgütsel Adalet Ölçüm Modeline Illişkin Değerler

\begin{tabular}{|c|c|c|c|c|}
\hline Örgütsel Adalet & $\begin{array}{l}\text { Standardize } \\
\text { Değerler }\end{array}$ & $\begin{array}{l}\text { Standart } \\
\text { Hatalar }\end{array}$ & t değerleri & $\overline{\mathrm{R}^{2}}$ \\
\hline \multicolumn{5}{|l|}{ Dağıtımsal Adalet -4 madde- } \\
\hline $\begin{array}{l}\text { Çalışma sonucunda elde ettiğiniz kazançlar işteki çabanıza } \\
\text { yansıyor mu? }\end{array}$ & 62 & 0,62 & 8,56 & 0,38 \\
\hline Elde ettiğiniz kazançlar yaptığınız işe uygun mu? & 60 & 0,64 & 8,24 & 0,36 \\
\hline Elde ettiğiniz kazançlar kuruma yaptığınız katkıya yansıyor mu? & ,70 & 0,51 & 9,82 & 0,49 \\
\hline $\begin{array}{l}\text { Göstermiş olduğunuz performans düşünülecek olursa, hakkınız } \\
\text { olanı elde ettiğiniz söylenebilir mi? }\end{array}$ & ,67 & 0,55 & 9,34 & 0,45 \\
\hline \multicolumn{5}{|l|}{ İşlemsel Adalet -7 madde- } \\
\hline $\begin{array}{l}\text { Hakkınızda karar verilirken görüşlerinizi ve duygularınızı ifade } \\
\text { edebiliyor musunuz? }\end{array}$ & ,62 & 0,62 & 8,81 & 0,38 \\
\hline Alınan kararlar üzerinde etkiniz var mı? & 68 & 0,54 & 9,88 & 0,46 \\
\hline Kararların alınma süreci tutarlı mı? & 71 & 0,50 & 10,57 & 0,50 \\
\hline Karar verilirken tarafsız davranılıyor mu? & 67 & 0,55 & 9,75 & 0,45 \\
\hline Karar verilirken süreçler doğru bilgilere dayandırılıyor mu? & 56 & 0,69 & 7,85 & 0,31 \\
\hline $\begin{array}{l}\text { Verilen kararlara itiraz ederek, durumun yeniden } \\
\text { değerlendirilmesini talep edebiliyor musunuz? }\end{array}$ & ,64 & 0,59 & 9,25 & 0,41 \\
\hline Sizce karar verilme süreci iş ahlakına uygun mu? & 52 & 0,73 & 7,16 & 0,27 \\
\hline St. Değerler & & & & \\
\hline Dağıtımsal Adalet $\longleftrightarrow$ İşlevsel Adalet & & & 15,93 & \\
\hline
\end{tabular}


Tablo 2. Örgütsel Bağlılık Ölçüm Modeline Ilişsin Değerler

\begin{tabular}{|c|c|c|c|c|}
\hline Örgütsel Bağlılık & $\begin{array}{l}\text { Standardize } \\
\text { Değerler }\end{array}$ & $\begin{array}{l}\text { Standart } \\
\text { Hatalar }\end{array}$ & değerleri & $\mathrm{R}^{2}$ \\
\hline \multicolumn{5}{|l|}{ Devam Bağlılığı -6 Madde- } \\
\hline $\begin{array}{l}\text { Şu an otelden ayrılmam, bundan sonraki hayatımda maddi zarara } \\
\text { uğramama neden olur. }\end{array}$ & 0,80 & 0,36 & 12,90 & 0,64 \\
\hline $\begin{array}{l}\text { Başka bir iş ayarlamadan bu otelden ayrıldığımda neler olacağı } \\
\text { konusunda endişe hissediyorum. }\end{array}$ & 0,57 & 0,68 & 8,24 & 0,32 \\
\hline Şu an kurumda kalmam, istekten ziyade gerekliliktir. & 0,68 & $\overline{0,54}$ & 10,26 & 0,46 \\
\hline $\begin{array}{l}\text { Bu kurumdan ayrılmayı düşünmek için çok az seçim hakkına sahip } \\
\text { olduğumu düşünüyorum. }\end{array}$ & 0,66 & 0,56 & 9,97 & 0,44 \\
\hline $\begin{array}{l}\text { Benim için bu otelden ayrılmanın olumsuz sonuçlarından biri de, } \\
\text { başka bir kurumun burada sahip olduğum olanakları sağlayamama } \\
\text { ihtimalidir. }\end{array}$ & 0,51 & 0,74 & 7,13 & 0,26 \\
\hline $\begin{array}{l}\text { Bu otelde çalışmaya devam etmemin önemli nedenlerinden biri de } \\
\text { ayrılmamın fedakarlık gerektirmesidir. }\end{array}$ & 0,49 & 0,76 & 6,86 & 0,24 \\
\hline Duygusal Bağlılık -6 Madde- & & & & \\
\hline Bu kuruma karşı duygusal bir bağ hissediyorum. & $\overline{0,62}$ & 0,62 & 7,51 & 0,38 \\
\hline Çalıştığım kurumdan dışarıdaki insanlara gururla bahsediyorum. & 0,59 & 0,65 & 10,93 & 0,35 \\
\hline Bu kurumda kendimi ailenin bir parçası gibi hissediyorum. & $\overline{0,63}$ & $\overline{0,60}$ & 14,16 & 0,40 \\
\hline $\begin{array}{l}\text { Kariyer hayatımın geriye kalanını bu otelde geçirmekten mutluluk } \\
\text { duyarım. }\end{array}$ & 0,68 & 0,54 & 8,68 & 0,46 \\
\hline $\begin{array}{l}\text { Çalıştığım otelin problemlerini kendi problemlerim gibi } \\
\text { hissediyorum. }\end{array}$ & 0,58 & 0,66 & 13,38 & 0,34 \\
\hline Çalıştığım kuruma karşı güçlü bir aidiyet duygusu hissediyorum. & 0,68 & 0,54 & 8,05 & 0,46 \\
\hline
\end{tabular}


Tablo 2. Örgütsel Bağlıık Ölçüm Modeline Iilişkin Değerler (Devamı)

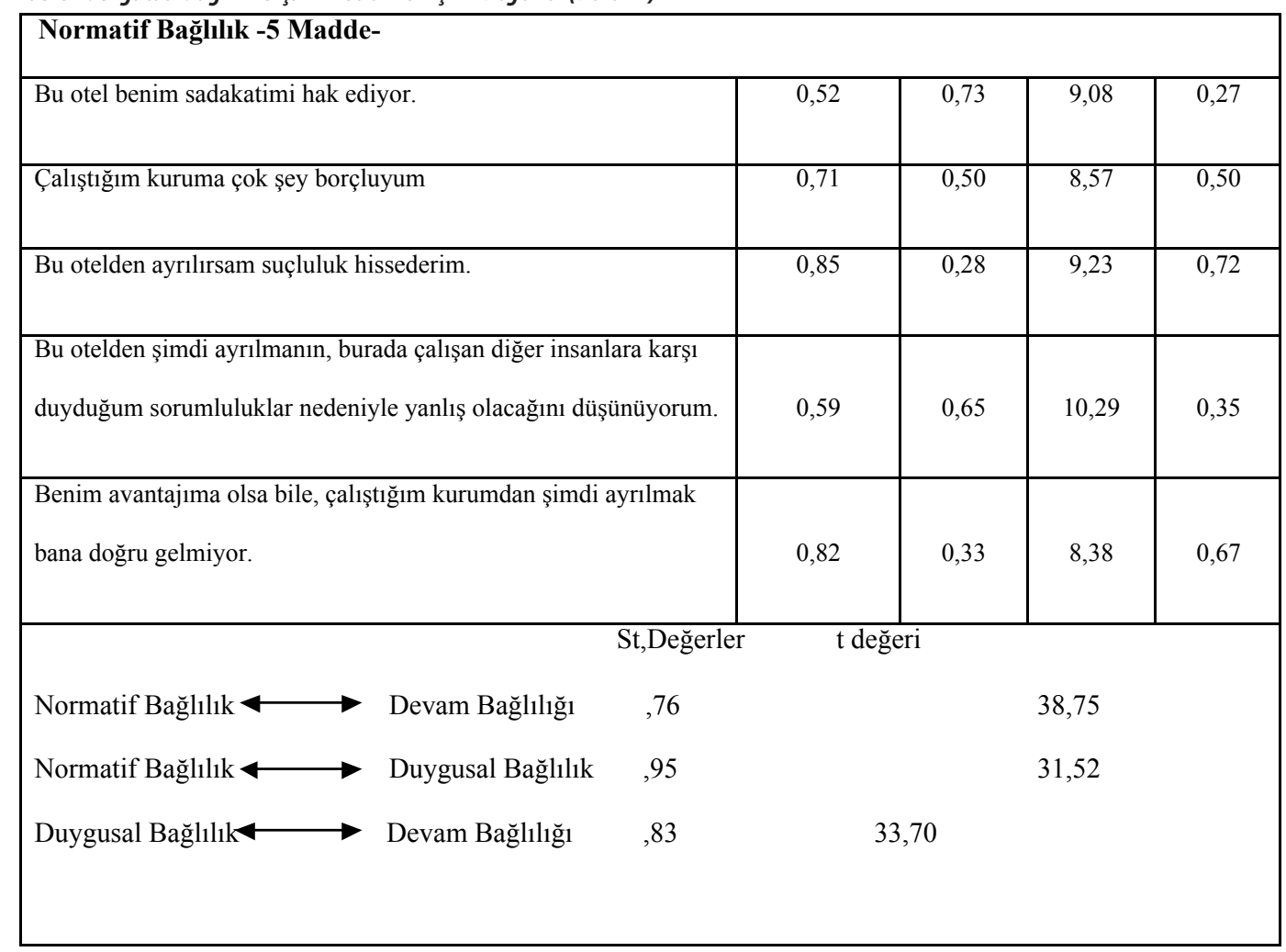

gütsel güven ölçeğine ilişkin değerlere bakıldığında standardize değerlerin l'in altında, $t$ değerlerinin 1,96’n üzerinde olduğu görülmektedir. Ancak ölçme modelleri bir bütün olarak değerlendirirken uyum iyiliği indekslerine bakılmaktadır. Literatürde en yaygin kullanılan uyum indekslerinin referans aralıkları (Kline, 2005, s.134) ve ölçme modellerine ait uyum iyiliği değerleri Tablo 4.de verilmiştir.

Hair vd. (2010, s.721) normalleştirilmiş ki-kare olarak ifade edilen $X^{2} / \mathrm{df}$ 'nin 2'nin altında olması durumunda modelin iyi bir model olduğunudu, 5'in altında olması durumunda ise modelin kabul edilmesi için yeterli olduğunu; ayrıca RMSEA’nın \%95 güven düzeyinde 0,10 'ın altında olması durumunda modelin kabul edilebileceğini belirtmiştir. Tablo 4.de yer alan ve araştırmada kullanılan modellerin (ölçme araçlarının) uyum iyiliği değerlerinin Hair vd. (2010, s.721) ve Kline’a (2005, s.134) göre kabul edilebilir değerler arasında olduğunu söylemek mümkündür.
Ölçeklerin güvenilirlik değerleri (Cronbach' Alfa), ortalama değerleri, standart hataları ve değişkenler arası ilişki değerleri Tablo 5.de verilmiştir. Tabloya bakıldığında dağıtımsal adaletin örgütsel güven $(r=0,549 p<0,01)$ ve örgütsel bağlllık $(r=0,471$ $\mathrm{p}<0,05)$ ile anlamlı ve aynı yönde ilişkili olduğu; işlemsel adaletin örgütsel güven $(r=0,712 \mathrm{p}<0,01)$ ve örgütsel bağlılık $(\mathrm{r}=0,429 \mathrm{p}<0,05)$ ile anlamlı ve aynı yönde ilişkili olduğu görülmektedir. Ayrıca örgütsel güven ve örgütsel bağllilk arasında $(\mathrm{r}=0,29 \mathrm{p}<0,05)$ anlamlı ve pozitif bir ilişki olduğu da görülmektedir.

Dağıtımsal ve işlemsel adaletin, örgütsel bağlllık üzerindeki etkisinde örgütsel güvenin aracılık rolünü test etmek için Baron ve Kenny (1986, s.1173-1182) tarafından önerilen yöntem tercih edilmiştir. Bu nedenle doğrudan ve dolaylı etkileri aynı anda görebilmek için iki ayrı yapısal eşitlik modeli kurgulanmış ve test edilmiştir. Birinci modelde bağımsız değişken olan işlemsel ve dağıtımsal adaletin bağımlı değişken olan örgütsel bağlllık üzerindeki etkisi test edilmiştir. 
Tablo 3. Örgütsel Güven Ölçeğine Ilişskin Doğrulayıc Faktör Analizi Değerleri

\begin{tabular}{|c|c|c|c|c|}
\hline Örgütsel Güven & $\begin{array}{c}\text { Standardize } \\
\text { Değerler }\end{array}$ & $\begin{array}{l}\text { Standart } \\
\text { Hatalar }\end{array}$ & $\begin{array}{c}\mathrm{t} \\
\text { değerleri }\end{array}$ & $\overline{\mathrm{R}^{2}}$ \\
\hline \multicolumn{5}{|l|}{ İşletmeye Güven -8 Madde- } \\
\hline Çalıştı̆ı̆m otel genelde açıklıkla yönetilir. & 0,58 & 0,66 & 8,12 & 0,34 \\
\hline $\begin{array}{l}\text { Çalıştığım otelde yöneticiler ve çalışanlar arasındaki güven düzeyi } \\
\text { çok yüksektir. }\end{array}$ & 0,19 & 0,96 & 2,39 & 0,04 \\
\hline Çalıştığım otel dürüst ve hakkaniyetli bir işleyişe sahiptir. & 0,60 & 0,64 & 8,49 & 0,36 \\
\hline Çalışanların özlük hakları konusunda adil davranır. & $\overline{0,43}$ & 0,82 & 5,79 & 0,18 \\
\hline Çalıştığım otel çalışanlarına ilgili ve saygılıdır. & 0,60 & 0,64 & 8,53 & 0,36 \\
\hline Çalıştığım otele her zaman güvenirim. & $\overline{0,42}$ & 0,82 & 5,67 & 0,18 \\
\hline $\begin{array}{l}\text { Çalıştığım otelde performans değerlendirmesini objektif olarak } \\
\text { yapmaktadır. }\end{array}$ & 0,45 & 0,80 & 6,10 & 0,20 \\
\hline Çalıştığım otel bütün çalışanlarına adil davranır. & 0,70 & 0,51 & 10,34 & 0,49 \\
\hline \multicolumn{5}{|l|}{ Yöneticiye Güven -9 Madde- } \\
\hline Yöneticim tutarlı biridir. & 0,74 & 0,45 & 11,19 & 0,55 \\
\hline Yöneticim astlarının hak ve çıkarlarını korur. & 0,63 & 0,60 & 9,15 & 0,40 \\
\hline Yöneticim verdiği sözleri daima tutar. & 0,29 & 0,92 & 3,38 & 0,08 \\
\hline Yöneticim çalışanlarını destekleyicidir. & 0,59 & 0,65 & 8,44 & 0,35 \\
\hline Yöneticim aldığı kararlarda çalışanların da katılımını sağlar. & 0,47 & 0,78 & 6,37 & 0,22 \\
\hline Yöneticim olumlu bir çalışma ortamı yaratır. & 0,60 & 0,64 & 8,53 & 0,36 \\
\hline Yöneticim işinde yeterli bilgi ve beceriye sahiptir. & 0,52 & 0,73 & 7,25 & 0,27 \\
\hline Yöneticim gerginlik yaratmaz. & 0,28 & 0,92 & $-3,74$ & 0,08 \\
\hline Yöneticim yardımsever biridir. & 0,38 & 0,86 & 10,19 & 0,14 \\
\hline
\end{tabular}


Tablo 3. Örgütsel Güven Ölçeğine İlişkin Doğrulayıcı Faktör Analizi Değerleri (Devamı)

\begin{tabular}{|c|c|c|c|c|}
\hline \multicolumn{5}{|l|}{ Çalışma Arkadaşlarına Güven -8 Madde- } \\
\hline Çalışma arkadaşlarım her türlü zorlukta bana yardım ederler. & 0,69 & 0,52 & 6,45 & 0,48 \\
\hline Çalışma arkadaşlarım sorumluluk sahibidirler. & 0,56 & 0,69 & 7,73 & 0,31 \\
\hline Çalışma arkadaşlarım dürüst ve açıktırlar. & 0,69 & 0,52 & 9,85 & 0,48 \\
\hline $\begin{array}{l}\text { Çalışma arkadaşlarım politik (içten pazarlıklı) davranışlar } \\
\text { sergilemezler. }\end{array}$ & 0,19 & 0,96 & $-2,37$ & 0,04 \\
\hline Çalışma arkadaşlarım mesleki becerileri oldukça yüksektir. & 0,48 & 0,77 & 6,49 & 0,23 \\
\hline Çalışma arkadaşlarım uyumludurlar. & 0,57 & 0,68 & 7,82 & 0,32 \\
\hline Çalışma arkadaşlarımın arasındaki güven düzeyi çok yüksektir. & 0,55 & 0,70 & 7,54 & 0,30 \\
\hline Çalışma arkadaşlarım işyerindeki kuralları istismar etmezler. & 0,57 & 0,68 & 7,85 & 0,32 \\
\hline \multicolumn{2}{|c|}{ St.Değerler } & $t$ değe & & \\
\hline İşletmeye Güven $\longleftrightarrow$ Yöneticiye Güven & & 22.09 & & \\
\hline İşletmeye Güven $\longleftrightarrow$ Çalışma Arkadaşlarına Güven & & .80 & 15.63 & \\
\hline Yöneticiye Güver $\longrightarrow$ Çalışma Arkadaşlarına Güven & & .74 & 13.85 & \\
\hline
\end{tabular}

Tablo 4. Ölçeklerin Doğrulayıcı Faktör Analizi Sonuçları

\begin{tabular}{|c|c|c|c|c|c|}
\hline \multirow[t]{2}{*}{ Gösterge / İndeks } & \multicolumn{3}{|c|}{ Ölçek/Model } & \multicolumn{2}{|c|}{ Referas Değerler } \\
\hline & $\begin{array}{c}\text { Örgütsel } \\
\text { Adalet }\end{array}$ & $\begin{array}{l}\text { Örgütsel } \\
\text { Bağlılık }\end{array}$ & $\begin{array}{l}\text { Örgütsel } \\
\text { Güven }\end{array}$ & $\begin{array}{c}\text { İyi Uyum İyiliği } \\
\text { Değeri }\end{array}$ & $\begin{array}{c}\text { Kabul Edilebilir } \\
\text { Uyum İyiliği } \\
\text { Değeri }\end{array}$ \\
\hline $\begin{array}{l}X^{2} / \mathrm{df} \\
\left(\text { Normalleştirilmiş } X^{2}\right)\end{array}$ & 2,45 & 2,36 & 2,22 & $0 \leq X^{2} / \mathrm{df} \leq 2$ & $2<X^{2} / \mathrm{df} \leq 5$ \\
\hline $\begin{array}{l}\text { RMSEA } \\
\text { Root Mean Square Error of Approx }\end{array}$ & 0,077 & 0,032 & ,064 & $0 \leq \mathrm{RMSEA} \leq 0,05$ & $0,05<$ RMSEA $\leq 0,08$ \\
\hline $\begin{array}{l}\text { GFI } \\
\text { Goodness Fit Index }\end{array}$ & ,92 & ,93 & ,87 & $0,95 \leq \mathrm{GFI} \leq 1,00$ & $0,90 \leq \mathrm{GFI}<0,95$ \\
\hline $\begin{array}{l}\text { AGFI } \\
\text { Adjusted Goodness of Fit Index }\end{array}$ & 88 & ,90 & ,93 & $0,90 \leq \mathrm{AGFI} \leq 1,00$ & $0,85 \leq \mathrm{AGFI}<0,90$ \\
\hline $\begin{array}{l}\text { SRMR } \\
\text { Standardize Root Mean Square } \\
\text { Residual }\end{array}$ & ,062 & ,041 & ,083 & $0 \leq \mathrm{SRMR} \leq 0,05$ & $0,05<$ SRMR $\leq 0,10$ \\
\hline $\begin{array}{l}\text { CFI } \\
\text { Comparative Fit Index }\end{array}$ & ,97 & ,93 & ,91 & $0,97 \leq \mathrm{CFI} \leq 1,00$ & $0,95 \leq \mathrm{CFI}<0,97$ \\
\hline
\end{tabular}


Tablo 5. Değiş̧enlere Ait Korelasyon ve Güvenirlik Değerleri

\begin{tabular}{|c|c|c|c|c|}
\hline Değişkenler & 1 & 2 & 3 & 4 \\
\hline 1. Dağıtımsal Adalet & 1 & & & \\
\hline 2. İşlemsel Adalet &, 633 & 1 & & \\
\hline 3. Örgütsel Güven &, $549 * *$ &, $712 * *$ & 1 & \\
\hline 4. Örgütsel Bağl1lık & ,471* & $429 *$ & ,290* & 1 \\
\hline Ortalama & 3,056 & 3,381 & 3,158 & 4,180 \\
\hline Standart Hata & 1,002 & 0,912 & 1,218 & 0,807 \\
\hline Cronbach's Alfa & 0,811 & 0,778 & 0,815 & 0,692 \\
\hline
\end{tabular}

${ }^{*} \mathrm{p}<, 05{ }^{* *} \mathrm{p}<, 01$

Model testi sonucu elde edilen uyum iyiliği değerleri, modelin kabul edilebilir bir model olduğunu göstermektedir $\left(X^{2} / \mathrm{df}=3,58\right.$; RMSEA $=0,061 ; \mathrm{GFI}=0,94$; AGFI $=0,84$ SRMR $=0,046$ CFI $=0,89$ ).

Şekil 2.de Model I'e ait ait standardize edilmiş beta değerleri ve $t$ değerleri yer almaktadır. Elde edilen bulgulara göre dağıtımsal adaletin örgütsel bağlılık üzerinde (standardize edilmiş $\beta=0,381 ; p<0,05$ ) ve işlemsel adaletin örgütsel bağlllık üzerinde (standardize edilmiş $\beta=0,249 ; p<0,05)$ olumlu bir etkisi bulunmaktadır. Bu olumlu etkiler, $\mathrm{H}_{1 \mathrm{a}}$ ve $\mathrm{H}_{1 \mathrm{~b}}$ hipotezlerini desteklemektedir.

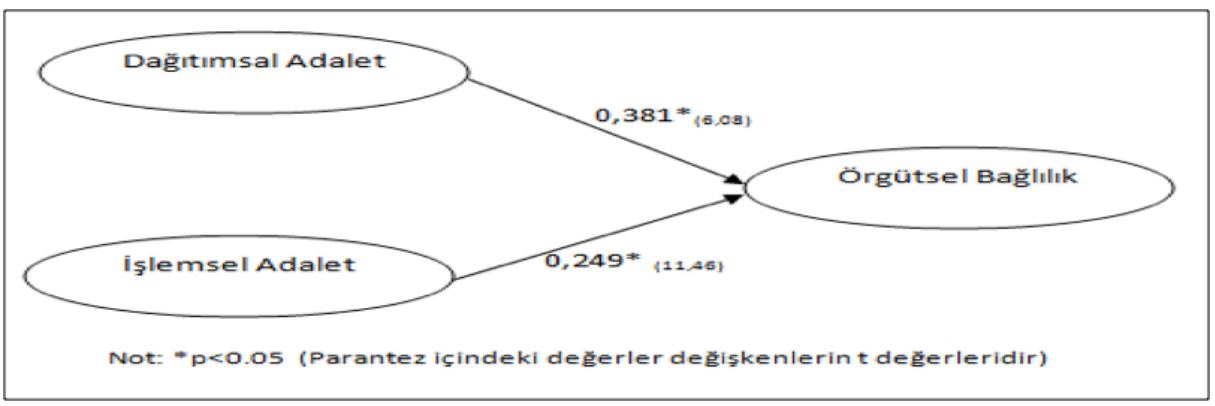

Şekil 2. Model 1- Bağımsız Değişkenin Bağımlı Değişken Üzerindeki Etkisi

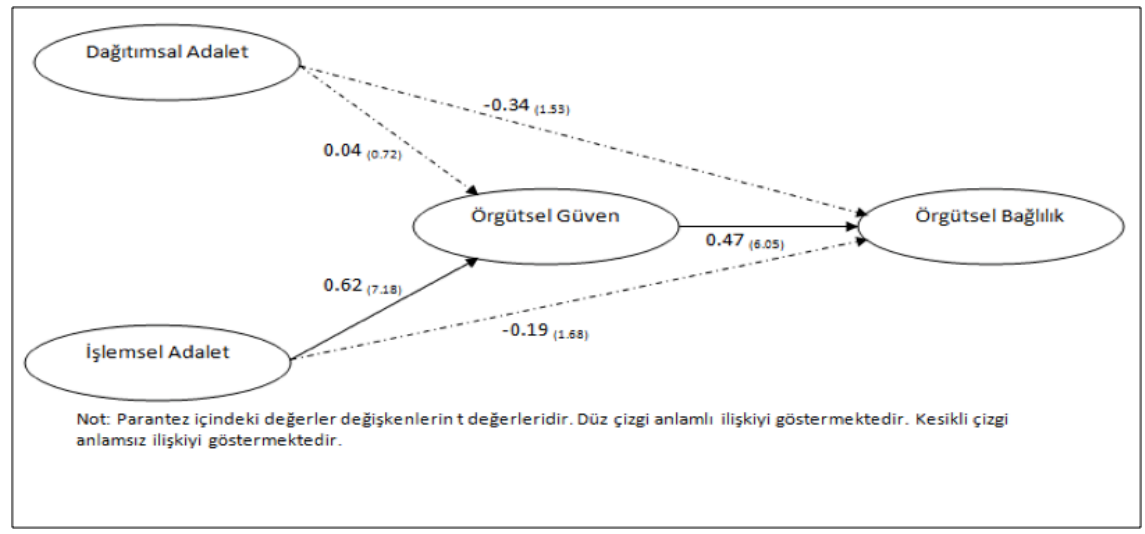

Şekil 3. Yapısal Eşitlik Modeli 
İkinci modelde örgütsel bağlılık değişkeni bağımli; dağıtımsal adalet ve işlemsel adalet değişkeni bağımsız; örgütsel güven ise aracı değişken olarak analize dahil edilerek, ikinci ve üçüncü etkilerin varlığı tek bir model üzerinde test edilmiştir. Şekil 3.de gösterilen modelin test edilmesi sonucunda uyum iyiliğ indeksleri $\quad\left(X^{2} / \mathrm{df}=4.16 ; \quad \mathrm{RMSEA}=0.042 \quad \mathrm{GFI}=0.89\right.$; AGFI $=0.93$ SRMR $=0.069$ CFI $=0.91$ ) kabul edilebilir sınırlar içerisinde bulgulanmıştır. Tablo 6'da modelde belirtilen yollara ait standardize edilmiş beta ve $\mathrm{p}$ değerleri yer almaktadır.

\begin{tabular}{|c|c|c|c|}
\hline Yol & & Standardize $\boldsymbol{\beta}$ & $\mathrm{P}^{*}$ \\
\hline Dağıtımsal Adalet & Örgütsel Güven & ,04 & 5,51 \\
\hline İşlemsel Adalet & Örgütsel Güven & ,62 &, 01 \\
\hline Dağıtımsal Adalet & Örgütsel Bağllılık &,- 34 & ,64 \\
\hline İşlemsel Adalet & Örgütsel Bağlllık &,- 19 &, 34 \\
\hline Örgütsel Güven & Örgütsel Bağll1lı &, 47 &, 01 \\
\hline
\end{tabular}

Elde edilen bulguların yer aldığı Tablo 6.'ya göre; örgütsel güvenin örgütsel bağlllık üzerinde anlamlı ve pozitif bir etkisi vardır (standardize edilmiş $\beta=0,47$; $\mathrm{p}<0,05)$. İşlemsel adaletin örgütsel güven üzerindeki etkisi pozitif ve anlamlı (standardize edilmiş $\beta=0,62$; $\mathrm{p}<0,05)$ olmasına rağmen; dağıtımsal adaletin örgütsel güven üzerindeki etkisi, $\% 5$ anlamlılık düzeyinde istatistiksel olarak anlamlı çıkmamıştır (standardize edilmiş $\beta=0,04 ; p<0,05)$. Aracılık etkisine bakıld ${ }^{-}$ ğında işlemsel adaletin örgütsel bağlllık üzerindeki etkisinin de istatistiksel olarak anlamlı olmadığı gö- rülmektedir (standardize edilmiş $\beta=-0,34 ; \mathrm{p}<0,05$ ). Bu nedenle işlemsel adalet ile örgütsel bağlllık arasındaki ilişkide örgütsel güvenin tam aracıllk etkisi bulunduğu söylenebilir. Ayrıca dağıtımsal adaletin örgütsel bağlllık üzerindeki etkisinde, örgütsel güvenin aracılık etkisine ilişkin bir bulguya rastlanılmamıştır. Bu sonuçlar $\mathrm{H}_{2 \mathrm{~b}}, \mathrm{H}_{3}$ ve $\mathrm{H}_{4 \mathrm{a}}$ hipotezlerini desteklemesine rağmen; $\mathrm{H}_{2 \mathrm{a}}$ ve $\mathrm{H}_{4 \mathrm{~b}}$ hipotezlerini desteklememektedir. Araştırma kapsamında önerilen hipotezler ve bu hipotezlere ilişkin yapısal eşitlik modeli test sonuçları Tablo 7'de özetlenmiștir.

Tablo 7. Yapısal Modelin Hipotez Test Sonuçları

\begin{tabular}{|c|c|}
\hline HIPOTEZ & SONUÇ \\
\hline $\mathrm{H}_{1 \mathrm{a}}$ : Dağıtımsal adaletin çalışanların örgütsel bağlılığı üzerinde olumlu bir etkisi vardır. & KABUL \\
\hline $\mathrm{H}_{1 b}$ : Isşlemsel adaletin çalışanların örgütsel bağlıllı̆ı üzerinde olumlu bir etkisi vardır. & KABUL \\
\hline $\mathrm{H}_{2 \mathrm{a}}$ : Dağıtımsal adaletin çalışanların örgütsel güveni üzerinde olumlu bir etkisi vardır. & RED \\
\hline $\mathrm{H}_{2 \mathrm{~b}}$ : Isşlemsel adaletin çalıșanların örgütsel güveni üzerinde olumlu bir etkisi vardır. & KABUL \\
\hline $\mathrm{H}_{3}$ : Örgütsel güvenin çalışanların örgütsel bağlllığı üzerinde olumlu bir etkisi vardır. & KABUL \\
\hline $\mathrm{H}_{4 \mathrm{a}}$ : Örgütsel güven, işlemsel adalet ile örgütsel bağl1lık arasındaki ilişkide aracılık etkisine sahiptir. & KABUL \\
\hline $\begin{array}{l}\mathrm{H}_{4 b} \text { : Örgütsel güven, dağıtımsal adalet ile örgütsel bağlllık arasındaki ilişkide aracilık etkisine } \\
\text { sahiptir. }\end{array}$ & RED \\
\hline
\end{tabular}




\section{Sonuç ve Öneriler}

\section{Kuramsal Çıktılar}

Örgütsel adalet çalışanların davranışlarını, iş performanslarını ve örgütsel başarılarını (Cropanzano vd., 2007, s.34), örgütsel kazanımlarını ve performanslarını (Baldwin, 2007, s.1), stres düzeylerini (Judge ve Colquit, 2004, s.400), örgütsel vatandaşlıklarını (Jafari ve Bidarian, 2012, s.1817), iş tatminlerini (Zainalipour vd. 2010, s.1989), ücret tatminlerini (Roch ve Shanonck, 2006, s.299), meslektaş ilişkilerini ve verimliliklerini (Niehoff ve Moorman, 1993, 527-556; Forret ve Love, 2008, s.248-260), örgütsel davranışlarını (Bies, 1987, s.289) ve çalışanlar arasındaki bilgi paylaşımını (Yeşim ve Dereli, 2013, s.205) etkilediği yapılan araştırmalarla belirlenmiştir. İstanbul'da faaliyet gösteren otel işletmelerinde yapılan bu çalışmada örgütsel adalet algılarının çalışanların örgütsel bağlllıkları üzerinde anlamlı etkisinin olduğu belirlenmiştir. Bu etki, daha önce yapılan çalışma sonuçları ile benzerlik göstermektedir ve buna bağlı olarak çalışanların örgütsel adalet algılarının artıılması yoluyla örgütsel bağlılıklarının olumlu olarak etkinebileceğini söylemek mümkündür.

Örgütsel güvenin belirleyici faktörleri arasında yer alan örgütsel bağlllık (Halis vd. 2007, s.200), iş performans1 (Randall, 1990, s.361; Mathiue ve Zajac, 1990, s.171), örgütsel vatandaşlık (Bolat ve Bolat, 2008, s.75) ve işletme performansı (Steyrer vd. 2008, s.364) gibi pek çok olumlu örgütsel çıtııı etkilediği yapılan araştırmalarla ortaya konulmuştur. Ayrıca örgütsel güvenin hizmet iklimi ve işgören memnuniyeti (Chathoth vd. 2007, s.338; Dundar ve Tabancali, 2012, s.5779) ve örgütsel çıtılar üzerinde etkili olduğu (Kath vd., 2010, s.1492-1493), iş tatminini (Lee vd., 2013, s.412) ve örgütsel bağllllı̆̆ etkilediği (Demirel, 2008, s.150; Taşkın ve Dilek, 2010, s.43-44; Celep ve Yllmaztürk, 2012, s.5767) belirlenmiştir. İstanbul'da yapılan bu çalışmada da otel işletmelerinde çalışanların örgüte güvenmeleri durumunda, örgütsel bağlılıklarının arttığ belirlenmiştir. Yöneticilerinin ve çalışma arkadaşlarının güvenilir olduğuna inanan çalışanların, buna bağlı olarak örgütsel bağlllıklarının artacağını söylemek mümkündür.

Araştırma sonuçları, işlemsel adalet özelliklerinin desteklenmesi ile çalışanların örgütsel bağlılığının ve örgütsel güvenlerinin pozitif olarak etkilenebileceğini ortaya koymaktadır. Ayrıca örgütsel güvenin örgütsel bağlllık üzerinde pozitif etkisi olduğu görülmekle birlikte, işlemsel adalet özelliklerinin desteklenmesinin çalışanların örgütsel bağlllıkları üzerindeki etkisinde de aracılık rolü oynadığı bulgulanmaktadır. Öte yandan, davranışsal adalet özelliklerinin çalışanların örgütsel bağlılıkları üzerinde pozitif etkiye sahip olduğu belirlenmiştir. Ancak dağıtımsal adalet özellikleri ile örgütsel güven arasında bir etkileşim bulunmaması nedeniyle aracılık etkisinden söz edilememektedir.

\section{Uygulamaya Yönelik Çıktılar}

İstanbul'da faaliyet gösteren otel çalışanları örnekleminde yapılan bu çalışmada dağıtımsal ve işlemsel adaletin çalışanların örgütsel bağlılıklarını artırıcı etkiye sahip olduğu belirlenmiştir. Bu etkiye bağlı olarak otel yöneticilerinin çalıșanlarının bağlılıkları$\mathrm{n} ı$ artırmak istediklerinde örgütsel adalet uygulamalarına önem vermelerinin yararlı olacağını söylemek mümkündür. Özellikle yöneticilerin çalışanların elde ettiği kazanç ve gösterdikleri çaba arasındaki ilişkiyi adil olarak düzenlemesi ve örgütteki karar alma sürecini etik değerlere bağlı olarak sürdürmeleri çalışanların örgütsel bağlllıklarının artmasına katkıda bulunabilir.

Bu çalışma kapsamında örgütsel bağlilığın, çalışanların örgüte olan güvenlerinden olumlu olarak etkilendiği belirlenmiştir. Bu etkiye bağlı olarak yöneticilerin örgütsel güveni artıracak uygulamalarının, çalışanların örgütsel bağlılıklarını da artıracabileceğini söylemek mümkündür. Ayrıca terfilerde, ödüllendirmelerde/ cezalandırmalarda, kişilerarası ilişkilerde adil ve tutarlı davranışlar göstererek yönetİcilerin, çalışanların örgüte güvenlerini artırabileceği düşünülebilir.

İstanbul'da yapılan bu çalışmada işlemsel adalet uygulamalarını örgütsel bağlılık ile olan ilişkisinde, örgütsel güvenin aracıllk etkisine sahip olduğu belirlenmiştir. Bu etki, örgüt içerisindeki işlemsel adalet uygulamalarının çalışanların örgütsel güvenlerini artırmasına bağlı olarak örgütsel bağlılıklarını da arttırtığ 1 şeklinde yorumlanabilir. Yöneticilerin örgüt içerisindeki kararlarını objektif ve iş ahlakına uygun olarak vermeleri, çalışanların örgütsel güvenleri üzerinde pozitif etki yaratarak örgütsel bağlllıklarının artmasına katkıda bulunabilecektir. 


\section{Çalışmanın Sınırılııkları ve Yapılacak Çalışmalar İçin Öneriler}

Bu çalışma otel çalışanlarının örgütsel güven, bağl1lık ve adalet algıları konusunda literatüre ve uygulamaya dönük katkılar barındırmasına rağmen, belirli kısıtlara da sahiptir. Bunlardan ilki, araştırmada veri toplama süreci yaklaşı olarak 5 ay devam etmesine rağmen, evreni temsil edecek yeterli örneklem büyüklüğüne ulaşılamamıştır. Ayrıca tercih edilen kolayda örnekleme yöntemi çalışmanın diğer kısıtını oluşturmaktadır. Bundan sonraki çalışmalarda departmanlardaki işgücü yoğunluğu dikkate alınarak yapılacak kota örneklemesi ile bu kısitın ortadan kaldırılabileceği düşünülmektedir. Bir diğer kısıt ise bu çalışmanın İstanbul ili örneklemindeki 5 yıldızlı otel çalışanları kapsamında yapılmasıdır. Konum, büyüklük, hizmet standardı, yönetim şekli (zincir otel veya bağımsız otel) esas alınarak farklı özelliklere sahip otel işletmeleri örnekleminde ve diğer turizm işletmelerinde (seyahat acenteleri, yiyecek-içecek işletmeleri ve ulaştırma işletmeleri) yapılacak olan çalışmalarda değişik sonuçlar elde edilmesi de olası bir durum olarak değerlendirilmelidir. $\mathrm{Bu}$ nedenle, bu çalışma kapsamında önerilen araştırma modelinin, farklı nitelikteki turizm işletmelerinde test edilmesi ile hem literatüre hem de uygulamaya katkı sağlayacağı düşünülmektedir.

Bu çalışmada, Colquitt (2001, s.389) tarafından geliştirilen Örgütsel Adalet Ölçeği, Tokgöz ve Aytemiz Seymen (2013, s.67) tarafından uyarlanan Örgütsel Güven Ölçeği ve Meyer ve Allen (1997) tarafindan geliştirilen Örgütsel Bağlılık Ölçeğinden yararlanılmıştır. Bu alandaki diğer çalışmalarda örgütsel güven ile ilgili olarak Chathoth vd. (2011, s.238) tarafindan geliştirilen Örgütsel Güven Ölçeği, örgütsel bağllılıla ilgili olarak Mowday vd. (1979, s.224) tarafindan geliştirilen Örgütsel Bağll1ık Ölçeği ve örgütsel adalet ile ilgili olarak Niehoff ve Moorman (1993, s.527-556) tarafından geliştirilen Örgütsel Adalet Ölçeği kullanılabilir. Ayrıca yapılacak çalışmalarda örgütsel adalet, örgütsel bağlllık ve örgütsel güven ile birlikte kişilik özelliklerine ve iş performansına ilişkin ifadelere yer verilmesi daha farklı hipotezlerin sinanmasına ve yeni çıkarımlarda bulunulmasına katkı sağlayabilir.

\section{Kaynakça}

Angle, H. L, Perry, J. L. (1986). Dual Commitment Andlabour-Ma Nagement Relationship Climates. Academy of Management Journal, 29, 31-50.

Aronson, E. (1999). The Social Animal. New York: Worth.

Arslantürk, G., Şahan, S. (2012). Örgütsel Adalet ve Örgütsel Bağllık Arasındaki İlişkinin Manisa İl Emniyet Müdürlügü Örnekleminde İncelenmesi. Polis Bilimleri Dergisi, 14 (1), 135-159.

Baldwin, S. (2006), Organisational justice, http://www. employment-studies.co.uk/pdflibrary/mp73.pdf/ (Erişim Tarihi: 12 Nisan 2012).

Baron, R. M., Kenny, D. A. (1986). The ModeratorMediator Variable Distinction in Social Psychological Research: Conceptual, Strategic and Statistical Considerations. Journal of Personality and Social Psychology, 51, 1173-1182. http://dx.doi. org/10.1037//0022-3514.51.6.1173

Bayrak Kök, S. (2006). İş Tatmini ve Örgütsel Bağlllığın İncelenmesine Yönelik Bir Araştırma. İktisadi ve İdari Bilimler Dergisi, 20 (1), 291-317.

Bentein, K., Vandenberg, R. J., Vandenberghe, C., Stinglhamber, F. (2005). The Role of Change in The Relationship between Commitment and Turnover: A latent growth Modeling Approach. The Journal of Applied Psychology, 90, 468-482. http://dx.doi. org/10.1037/0021-9010.90.3.468

Bies R. J. (1987). The Predicament of Injustice: The Management of Moral Outrage. Cummings L.L, Staw B.M. (Eds)., Research in Organizational Behaviour içinde, (s. 289-319). Greenwich, CT: JAI

Bies, R. J., Moag, J. F. (1986). Interactional Justice: Communication Criteria of Fairness. R. J. Lewicki, B. H. Sheppard, \& M. H. Bazerman (Eds.), Research on Negotiations in Organizations içinde (s. 4355). Greenwich, CT: JAI.

Bolat, O. İ., Bolat, T. (2008). Otel İşletmelerinde Örgütsel Bağlllık ve Örgütsel Vatandaşlık Davranışı İlişkisi. Balıkesir Üniversitesi Sosyal Bilimler Enstitüsü Dergisi, 11 (19),75-94. 
Brown B. B. (2003). Employees' Organizational Commitment and Their Perception of Sypervisors' Relation-Oriented Leadership Behaviors. (Yayınlanmamıș Yüksek Lisans Tezi). Virginia/Falls Church.

Celep, C., Yilmazturk, O.E. (2012). The Relationship among Organizational Trust, Multidimensional Organizational Commitment and Perceived Organizational Support in Educational Organizations. Social and Behavioral Sciences, 46, 5763-5776. http://dx.doi.org/10.1016/j.sbspro.2012.06.512

Chathoth, P.K., Mak, B., Jauhari, V., Manaktola, K. (2007). Employees' Perceptions of Organizational Trust And Service Climate: A Structural Model Combining Their Effects on Employee Satisfaction. Journal of Hospitality and Tourism Research, 31 (3), 338-357. http://dx.doi. org/10.1177/1096348007299922

Chathoth, P.K., Mak, B., Sim, J., Jauhari, V., Manaktola, K. (2011). Assessing Dimensions of Organizational Trust Across Cultures: A Comparative Analysis of U.S. and Indian Full Service Hotels. International Journal of Hospitality Management, 30, 233-242. http://dx.doi.org/10.1016/j.ijhm.2010.09.004

Chow,I. H.S. (1994). Organizational Commitment and Career Development of Chinese Managers in Hong Kong and Taiwan. International Journal of Career Management, 6 (4), 3-9. http://dx.doi. org/10.1108/09556219410066646

Colquitt, J. A. (2001). On The Dimensionality of Organizational Justice: A Construct Validation of A Measure. Journal of Applied Psychology, 86, 386-400. http://dx.doi.org/10.1037//0021-9010.86.3.386

Cropanzano, R., Bowen, D. E., Gilliland, W. S. (2007). The Management of Organizational Justice. Academy of Management Perspectives, 21, 34-47. http:// dx.doi.org/10.5465/AMP.2007.27895338

Çakıcı, A. C., Yılmaz, B.E. (2012). Mersin'deki Otel Çalışanlarının Nükleer Kaygıları, Çevresel Yaklaşım ve Çevreci Tüketim Eğilimleri Üzerine Bir Araştırma. Çağ Üniversitesi Sosyal Bilimler Dergisi, 9, (2), 1-22.

Çakınberk, A., Demirel, E.T. (2010). Örgütsel Bağll11ğın Belirleyicisi Olarak Liderlik: Sağlık Çalışanları Örneği. Selçuk Üniversitesi Sosyal Bilimler Enstitüsü Dergisi, 24, 103-119.
DeConnick, J.B. (2010). The Effect of Organizational Justice, Perceived Organizational Support, and Perceived Supervisor Support on Marketing Employees' Level of Trust. Journal of Business Research, 63 (12), 1349-1355.

Deluga, R. J. (1994). Supervisor Trust Building, Leader-Member Exchange and Organizational Citizenship Behaviour. Journal of Occupational and Organizational Psychology, 67, 315-326. http:// dx.doi.org/10.1111/j.2044-8325.1994.tb00570.x

Demircan, N., Ceylan, A. (2003). Örgütsel Güven Kavramı: Nedenleri ve Sonuçları. Celal Bayar Üniversitesi İktisadi ve İdari Bilimler Fakültesi Yönetim ve Ekonomi Dergisi, 10 (2), 139-150.

Demirel, Y. (2008). Örgütsel Adaletin Yönetici-Çalışan İlişkileri Üzerine Etkisi: Farklı Sektör Çalışanlarına Yönelik Bir Araştırma. SÜ İIBF Sosyal ve Ekonomik Araştırmalar Dergisi, 9 (17), 137-154.

Dirks, K., Ferrin, D. (2001). The Role of Trust in Organizational Settings. Organization Science, 12 (4), 450-467. http://dx.doi.org/10.1287/ orsc. 12.4 .450 .10640

Dundar, T., Tabancali, E. (2012). The Relationship between Organizational Justice Perceptions and Job Satisfaction Levels. Social and Behavioral Sciences, 46, 5777 - 5781. http://dx.doi.org/10.1016/j. sbspro.2012.06.513

Forret M., Love M.S. (2008). Employee Justice Perceptions and Co-Worker Relationships. Leadership and Organizational Development Journal, 29(3):248-260.

Greenberg, J. A. (1993). The social side of fairness: Interpersonal and Informational Classes of Organizational Justice. R. Cropanzano (Ed.), Justice in The Workplace: Approaching Fairness iHuman Resource Management içinde (s. 79-103). NJ: Lawrence Erlbaum.

Gregory, D. M., Way, C. Y., LeFort, S., Barrett, B. J., Parfrey, P. S. (2007). Predictors of Registered Nurses' Organizational Commitment and Intent to Stay. Management Review, 32, 119-127.

Hair, J. F. Jr., Black, W.C., Babin, B.J., Anderson, R.E.. (2010). Multivariate Data Analysis, NJ: Pearson. 
Halis, M., Gökgöz, G.S., Yaşar, Ö. (2007). Örgütsel Güvenin Belirleyici Faktörleri ve Bankacılık Sektöründe Bir Uygulama. Sosyal Bilimler Dergisi, 17, 187-205.

Hon, A.H.Y., Lu, L. (2010). The Mediating Role of Trust between Expatriate Procedural Justice and Employee Outcomes in Chinese Hotel Industry. International Journal of Hospitality Management, 29, 669676. http://dx.doi.org/10.1016/j.ijhm.2010.01.002

İşcan, Ö. F., Naktiyok, A. (2004). Çalışanların Örgütsel Bağdaşımlarının Belirleyicileri Olarak Örgütsel Bağlilık ve Örgütsel Adalet Algıları. Ankara Üniversitesi Siyasal Bilgiler Fakültesi Dergisi, 59 (1), 181-201.

İşcan, Ö.F., Sayın, U. (2010). Örgütsel Adalet, İş Tatmini ve Örgütsel Güven Arasındaki İlişki. Atatürk Üniversitesi İktisadi ve İdari Bilimler Dergisi, 24 (4), 195-216.

Jafari, P., Bidarian, S. (2012). The Relationship between Organizational Justice and Organizational Citizenship Behavior. Social and Behavioral Sciences, $47,1815-1820$.

Johnson, E. R., Selenta, C., Lord, R. G. (2006). When Organizational Justice and The Self-Concept Meet: Consequences for The Organization and Its Members. Organizational Behavior and Human Decision Processes, 99, 175-201. http://dx.doi.org/10.1016/j. obhdp.2005.07.005

Judge, T. A., Colquit, J. A. (2004). Organizational Justice and Stress: The Mediationg Role of WorkFamily Conflict. Journal of Applied Psychology, 89 (3), 395-404.

Kath, L. M., Magley, V. J., Marmet, M. (2010). The Role of Organizational Trust in Safety Climate's Influence on Organizational Outcomes. Accident Analysis and Prevention, 42, 1488-1497.

Koys, D.J, DeCotiis, T.A. (1991). Inductive Measures of Psychological Climate, Human Relations, 44 (3), 265-276. http://dx.doi. org/10.1177/001872679104400304

Kundi, B. A. T., Saleh, S. D. (1993). A Model of Organizational Commitment: Instrumental and İntrinsic Motivational and Beyond. Canadian Journal of Administrative Sciences, 10 (2), 154-166.
Lee, C.K., Song, H.J., Le, H.M., Lee, S., Bernhard, B.J. (2013). The Impact of CSR on Casino Employees' Organizational Trust, Job Satisfaction and Customer Orientation: An Empirical Examination of Responsibble Gambling Strategies. International Journal of Hospitality Management, 33, 406-415.

Mathiue, J.E., Zajac, D.M. (1990). A Review and Meta-Analysis of The Antecedents, Correlates, and Consepuences of Organizational Commitment. Psychological Bulletin, 108, 171-194. http://dx.doi. org/10.1037//0033-2909.108.2.171

Mayer, R., Davis, J., Schoorman, D. (1995). An Integrative Model of Organizational Trust, The Academy of Management Review, 20 (3), 709-734. http:// dx.doi.org/10.2307/258792

Mayer, Roger C., Gavin, Mark B. (2005). Trust in Management and Performance: Who Minds The Shop While The Employees Watch The Boss?. Academy of Management Journal, 48 (5), 874-888. http:// dx.doi.org/10.5465/AMJ.2005.18803928

McAllister, D. J. (1995). Affect-and Cognition-Based Trust as Foundations for Interpersonal Cooperation in Organizations. Academy of $\mathrm{Ma}$ nagement Journal, 38 (1), 24-59. http://dx.doi. org/10.2307/256727

McFarlin, D. B., Sweeney, P. D. (1992). Distributive and Procedural Justice as Predictors of Satisfaction with Personal and Organizational Outcomes. Academy of Managenment Journal, 35 (3), 626-637. http://dx.doi.org/10.2307/256489

Memduhoğlu, H.B., Zengin, M. (2011). İlköğretim Okullarında Örgütsel Güvene İlişkin Öğretmen Görüşleri. YYÜ Eğitim Fakültesi Dergisi, 8 (1), 211217.

Meyer, J. P., Allen, N. J. (1991). A Three-Component Conceptualization of Organizational Commitment, Human Resource Management Review, 1, 61-89. http://dx.doi.org/10.1016/10534822(91)90011-Z

Meyer, J. P., N. J. Allen (1997). Commitment in the Workplace - Theory, Research, and Application, Thousand Oaks, CA: Sage. http://dx.doi.org/10.1016/ S1053-4822(00)00053-X 
Mishra, J., Morrissey, M. (2000). Trust in Employee/ Employer Relationships: A Survey of West Michigan Managers, Seidman Business Review, 6 (1), 14-15.

Mowday, R. T., Steers, R. M., Porter, L. W. (1979). The Measurement of Organizational Commitment, Journal of Vocational Behavior, 14, 224-247. http:// dx.doi.org/10.1016/0001-8791(79)90072-1

Mullins L. J. (2007). Management and Organisational Behaviour. 8th ed. Harlow: FT Prentice Hall .

Niehoff B. ve Moorman R.H. (1993). Justice as a Mediator of The Relationship Between Methods of Monitoring and Organizational Citizenship Behaviour. Academy ofManagement Journal, 36 (3), 527 556. http://dx.doi.org/10.2307/256591

O'Reilly, C. (1989). Corporations, Culture, and Commitment: Motivation and Social Control in Organizations, California Management Review, 31, 1718. http://dx.doi.org/10.2307/41166436

Randall, D. M. (1990). The Consequences of Organisational Commitment: Methodological Investigation, Journal of Organisational Behavior, 11, 361378. http://dx.doi.org/10.1002/job.4030110504

Robbins, J.P., Judge, T.A. (2011). Organizational Behavior, Fourteenth Ed., NJ:Pearson.

Roch S.G., Shanock L.R. (2006). Organizational Justice in an Exchange Framework Clarifying Organisational Justice Distinctions, Journal of Management, 32 (2), 299-322. http://dx.doi. org/10.1177/0149206305280115

Sekaran, U. (1992). Research Methods for Business - A skill building approach. (2nd Ed). United States of America: John Wiley \& Sons, Inc.

Skarlicki, D. P., Folger, R. (1997). Retaliation in the Workplace: The Roles of Distributive, Procedural, and Interactional Justice. Journal of Applied Psychology, 82 (3), 434-443. http://dx.doi. org/10.1037//0021-9010.82.3.434

Steyrer, J., Schiffinger, M., Lang, R. (2008). Organizational Commitment-A missing Link Between Leadership Behavior and Organizational Performance. Scand. J.Mgmt., 24, 364-374.
Şahin, B., Taşkaya, S. (2010). Sağlık Çalışanlarının Örgütsel Adalet Algılarını Etkileyen Faktörlerin Yapısal Eşitlik Modeli ile İncelenmesi. Hacettepe Sağllk İdaresi Dergisi, 13 (2), 85-114.

Taşkın, F., Dilek, R. (2010). Örgütsel Güven ve Örgütsel Bağlılık Üzerine Bir Alan Araştırması. Organizasyon ve Yönetim Bilimleri Dergisi, 2 (1), 37-46.

Tokgöz, E., Aytemiz Seymen, O. (2013). Örgütsel Güven, Örgütsel Özdeşleşme ve Örgütsel Vatandaşlık Davranışları Arasındaki İlişki: Bir Devlet Hastanesinde Araştırma. Marmara Üniversitesi Sosyal Bilimler Enstitüsü Hakemli Dergisi, 10 (39), 61-79.

Tyler, T. R., Bies, R. J. (1990). Beyond Formal Procedures: The Interpersonal Context of Procedural Justice. J.S. Carroll (Ed.), Applied social psychology in business settings içinde (s.77-98). Hillsdale, NJ: Erlbaum.

Ural, A., Kılıç, İ. (2006). Bilimsel Araştırma Süreci ve SPSS ile Veri Analizi. Anakara: Detay.

Uyguç, N., Çımrın, D. (2004). DEÜ Arastırma ve Uygulama Hastanesi Merkez Laboratuarı Çalısanlarının Örgüte Baglılıklarını ve İșten Ayrılma Niyetlerini Etkileyen Faktörler. D.E.Ü İ.I.B.F. Dergisi, 19 (1), 91-99.

Whitener, E. M., Brodt, S. E., Korsgaard, M.A., Werner, J. M. (1998). Managers as Initiators of Trust: An Exchange Relationship Framework For Understanding Managerial Trustworthy Behavior. The Academy of Management Review, 23 (3), 513-530. http://dx.doi.org/10.2307/259292

Yeşil, S., Dereli, S. F. (2013). An Emprical Investigation of The Organisational Justice, Knowledge Sharing and Innovation Capability. Social and Behavioral Sciences, 75, 199-208.

Zainalipour, H., Fini, A .A. S., Mirkamali, S.M. (2010). A Study of Relationship between Organizational Justice and Job Satisfaction Among Teacher in Bandar Abbas Middle School, Social and Behavioral Sciences, 5, 1986-1990. http://dx.doi. org/10.1016/j.sbspro.2010.07.401 